\title{
Preliminary Early Childhood Teachers' Thoughts on Unification Education
}

\author{
예비유아 교사들의 통일 교육에 대한 생각 \\ Jong-Ae Kwon ${ }^{1}$ \\ 권종애 ${ }^{1}$ \\ ${ }^{1}$ Professor, Department of Early Childhood Education, Seowon University, South Korea, \\ angelpiano64@hanmail.net
}

\begin{abstract}
This study conducted both quantitative and qualitative research to find out about unification education for early childhood through the thoughts of preliminary pre-school teachers on unification education. Thirty-two preliminary early childhood teachers were selected as research participants, and data were collected by mixing the researcher and the face-to-face non-face-to-face method. Through this, the study explored the ideas of pre-primary early childhood teachers on unification education through data analysis , thematicization and categorization of texts. As a result, a total of 527 words were derived, including duplicated ones among the ones that came to mind when the preliminary early childhood teachers were unified. The results showed that $71.9 \%$ of the study participants needed unification, and a total of 261 items that should be prioritized for reconciliation between the two Koreas were selected. The derived items are 'culture art', 'physical education', 'music', 'cultural exchange', 'reorganization of Hangeul for language integration', 'bridging economic gaps and monetary and economic integration', 'curriculum and educational necessity', 'integration of political systems', 'recognition of differences and understanding and respect', 'hostility Abandonment', 'the necessity of diplomatic efforts in the international community' in sequence. The purpose of this study was not only to explore the implementation and alternatives of early childhood unification education through the thinking process of preliminary early childhood teachers on unification education, but also to find out the applicability of the early childhood education field and the direction.
\end{abstract}

Keywords: Preschool Teachers, Unification, Education, Thought

요약: 본 연구는 예비 유아 교사들의 통일 교육에 대한 생각을 통해 유아 통일 교육에 대해 알아보기 위한 양적, 질적 연구를 수행한 혼합연구이다. 연구참여자로 예비 유아 교사 32 명 을 선정하고, 연구자와 대면 비대면 방식을 혼합하여 자료를 수집하였다. 이를 통하여 자료 의 분석, 텍스트의 주제화 및 범주화를 통하여 예비 유아 교사들의 통일 교육에 대한 생각을 탐색하고자 하였다. 그 결과 예비 유아 교사들은 통일하면 생각나는 것 중에 중복되어 나타 난 것을 포함하여 총 527 개의 단어가 도출되었다. 연구참여자의 $71.9 \%$ 가 통일은 필요하다는 결과와 통일이 된다면 남북한 화합을 위해 가장 우선시 되어야 할 점은 총 261 개가 도출되었 다. 도출된 사항은 문화예술, 체육, 음악, 문화교류, 언어통합을 위한 한글의 재정비, 경제 적 격차 해소 및 화폐 경제통합, 교육과정 및 교육 필요성, 정치체제의 통합, 서로 다름 인정

Received: September 24, 2021; $1^{\text {st }}$ Review Result: November 10, 2021; $2^{\text {nd }}$ Review Result: December 25, 2021 Accepted: January 29, 2022

*이 논문은 2021 년 10 월 4 차 학술대회 발표논문을 수정보완하여 수행되었음. 
및 이해와 존중, 적대감 버리기, 국제사회에서 외교적 노력의 필요 순이다. 통일 교육에 대 한 예비 유아 교사들의 사고 과정을 통해 유아 통일 교육의 실행 및 대안을 모색해 볼 기회뿐 만 아니라 앞으로 유아교육 현장적용 가능성과 연구의 방향성을 알아보고자 하는 목적으로 연구를 수행하였다.

핵심어: 예비 유아교사, 통일, 교육, 생각

\section{1. 서론}

우리나라의 통일 교육은 정치적. 시대적 변화를 격어왔으며 분단 이후 '반공교육' , ‘통일 안보 교육' , '통일 교육' 으로 명칭이 바뀌면서 교육의 방향이나 강조점도 변화해왔다(이창식, 2020)[1]. 따라서 1980년대의 냉전 체제하의 통일 교육은 북한과의 적대감 속에서 반공과 안보 의식을 심어주는 데 치중했다면, 1990년대의 독일의 통일, 동유럽 및 구소련의 체제 변화와 국제환경의 변화는 통일 안보 교육에 치중할 수밖에 없었다. 2000년대 들어와서는 남 - 북 정상 간의 만남 이후 화해와 공존, 평화와 협력을 강조하는 대북관에 따라 통일 교육의 지향점도 변화되었다.

2018년 4월 27일 판문점 평화의 집에서 남북정상회담이 진행되었다. 한반도에 더는 전쟁은 없을 것이며 새로운 평화의 시대가 열리었음을 전 세계에 전해졌다. "냉전의 산물인 오랜 분단과 대결을 하루빨리 종식하고 민족적 화해와 평화 번영의 새로운 시대를 과감하게 일궈나가며 남북관계를 보다 적극적으로 개선하고 발전 시켜 나가야 한다” 는 확고한 의지를 담은 판문점 선언이 발표되었다. 또한, 2018년 9월 19일 평양공동선언에서 가장 큰 관심을 모았던 '비핵화 부분' 으로 군사, 경제, 이산가족, 문화, 비핵화 분야에 대한 주요 협약내용들은 대결과 대립을 끝내고 전쟁 종식이라는 진정한 평화 무드의 메시지였다. 특히 남과 북이 동서 회선 철도와 도로 연결을 위한 착공식을 하겠다는 점과 환경이 조성되는 대로 개성공단과 금강산 관광사업 정상화도 이뤄질 것이라는 점, 북한의 정상이 서울 땅을 밟는 것이야말로 남북관계가 완전히 정상화됐다는 기대감도 팽배했다. 지난 69년간 민족이 함께 듣고, 함께 외치고 싶었던 전쟁 없는 한반도, 새로운 한반도, 새로운 민족의 길이 펼쳐질 것이라 기대했다.

그러나 2020년 6월 16일 남북공동연락사무소가 무너져 내렸다. 남북대화의 상징이 폭파되어 사라져버렸다. 4.27 판문점 공동선언과 9.19 평양공동선언이 무너지고 한반도에 또다시 위기감이 일기 시작했다. 이러한 현 상황에서 교육을 담당하는 우리들은 어떠한 사고를 하고 통일 교육으로 접근할 것인지 과도기적 시기를 맞이하고 있다. 이런시점에 국가수준의 교육과정인 2019 개정 누리과정과 제 4 차 표준보육 과정이 유아 중심, 놀이 중심교육과정으로 개정되면서 사회관계 영역 안에 북한과 관련된 내용이 모두 사라졌음을 알 수 있다. 개정 누리과정에서 세부내용이 사라지고 연령별 기준도 사라짐으로 인해 기존 누리과정에서 명시하던 내용이 대폭 바뀌었기 때문이다. 이것은 교사의 자율성, 책무성을 강조하면서 교사의 역량에 따라 통일 교육이 이루어질 수도 있고 통일 교육이 실시되지 않을 수도 있음을 보여주는 것이라 여겨진다.

이러한 통일 교육에 대한 혼재는 어린 유아들을 가르치는 교사들에게 영향을 미칠 수 있다. 특히 유아기는 민감한 시기로 다른 문화와 사회에 대해 편견 없이 받아드릴 수 있는 태도를 지니며 다른 사람을 이해하고 공감하고 협력할 수 있는 소양이 필요한 
시기이다. 이러한 시점에서 북한에 대한 이해뿐만 아니라 평화와 통일 교육에 대한 이해를 통해 대한민국 국민으로서의 정체성, 세계 속의 한국인으로서의 정체성을 가질 수 있는 유아로 성장해 나갈 수 있어야 할 것이다.

유아 교사 대상으로 한 통일 교육 최근 연구를 살펴보면 유아 교사의 통일 교육 인식에 관한 연구(권종애, 2018; 김보영, 2015; 박문희, 2018, 최정란, 2017)[2-5], 유아 교사의 통일 교육역량에 관한 연구(곽연미, 2011)[6], 예비 유아 교사의 통일 - 통일 교육 인식에 대한 연구(김선혜, 2020)[7], 유아를 대상으로 실시한 통일 프로젝트 활동이 유아의 통일 인식과 갈등 인식 및 해결에 미치는 효과에 관한 연구(김성원 · 김수영, 2019)[8] 등이 있다. 유아 교사 대상 통일 교육에 대한 연구들은 대부분 양적 연구가 실시되고 있음을 알 수 있으며, 특히 유아 교사 대상 통일 교육 인식에 대한 연구들은 미흡하지만 이루어지고 있고, 예비 유아 교사의 통일 · 통일인식에 대한 최근 연구는 김선혜(2020)의 양적 연구만이 존재하므로 예비 유아 교사들의 통일 교육에 대한 생각이나 의식 등에 대한 연구는 미흡한 실정이고 질적 연구는 전무한 상태이다. 그러므로 현시점에서 예비 유아 교사들의 생각을 통해 유아 통일 교육에 대한 생각을 알아볼 필요가 있고, 분석해 볼 필요가 있겠다[7]. 이러한 예비 유아 교사들의 통일 교육의 인식과 흐름은 유아교육 과정 속에 통일 교육에 대한 철저한 준비가 될 수 있을 것이다. 통일 교육의 주체가 되는 유아들에게 가장 많은 영향을 줄 수 있는 사람은 유아 교사들이라는 점을 간과해서는 안 된다. 그리고 예비 유아 교사들의 통일에 대한 바람직한 인식과 사고는 유아 교사가 되었을 때 효율적인 통일 교육을 기대할 수 있기 때문이다.

그러므로 본 연구는 예비 유아 교사들의 통일 교육에 대한 생각을 연구함으로써 향후 통일 교육 정책 및 지원 방향을 모색하고자 한다. 특히 통일 교육에 대한 예비 유아 교사들의 사고 과정을 살펴보는 것에 초점을 맞추고자 한다. 예비 유아 교사들의 생각을 통해 유아 통일 교육에 대한 마음가짐과 교육을 위한 대안을 모색해 볼 수 있는 기회를 가지며 앞으로 유아 통일 교육이 유아교육 현장 적용 가능성과 방향성을 알아보고자 하는 목적으로 연구를 수행하였다. 이를 위해 설정된 연구 문제는 “예비 유아 교사들의 통일 교육에 대한 생각은 어떠한가?” 이다.

\section{2. 연구방법}

\section{1 연구 참여자}

본 연구참여자는 C 도시 S 대학교 유아교육과 학생 35명이다. 대학입학 후 생각하고, 글과 말로 표현할 기회를 통해 비판적 사고, 논리적 사고, 창의적 사고를 경험한다.

‘통일' 에 대한 생각을 할 수 있었고 ‘통일 교육' 이 현장에서 어떠한 방식으로 이루어질 것인지 가정적 사고로 자신들의 생각을 글과 말로 표현한 연구참여자 35 명 중 자료의 누락과 온라인 소통에 문제가 있었던 자료 3개를 제외한 32명의 예비 유아 교사를 대상으로 하였다. 이에 본 연구에 대한 설명을 듣고 동의해 준 예비유아 교사들을 연구 참여자로 선정하였으며 연구에서 이름은 사용하지 않고 알파벳으로 처리하였다. 연구 참여자 예비 유아 교사의 일반적인 특성은 [표 1]과 같다. 
[표 1] 연구대상의 일반적 특성

[Table 1] General characteristics of research subjects

\begin{tabular}{|c|c|c|c|c|c|c|c|}
\hline 사례 & 연구 참여자 & 성별 & 학년 & 사례 & 연구 참여자 & 성별 & 학년 \\
\hline 1 & $\mathrm{~A}$ & 여 & 1 & 17 & $\mathrm{Q}$ & 여 & 1 \\
\hline 2 & $\mathrm{~B}$ & 여 & 1 & 18 & $\mathrm{R}$ & 여 & 1 \\
\hline 3 & $\mathrm{C}$ & 여 & 1 & 19 & $\mathrm{~S}$ & 여 & 1 \\
\hline 4 & $\mathrm{D}$ & 여 & 1 & 20 & $\mathrm{~T}$ & 여 & 1 \\
\hline 5 & $\mathrm{E}$ & 여 & 1 & 21 & $\mathrm{U}$ & 여 & 1 \\
\hline 6 & $\mathrm{~F}$ & 여 & 1 & 22 & $\mathrm{~V}$ & 여 & 1 \\
\hline 7 & $\mathrm{G}$ & 여 & 1 & 23 & $\mathrm{~W}$ & 여 & 1 \\
\hline 8 & $\mathrm{H}$ & 여 & 1 & 24 & $\mathrm{X}$ & 여 & 1 \\
\hline 9 & $\mathrm{I}$ & 여 & 1 & 25 & $\mathrm{Y}$ & 여 & 1 \\
\hline 10 & $\mathrm{~J}$ & 여 & 1 & 26 & $\mathrm{Z}$ & 여 & 1 \\
\hline 11 & $\mathrm{~K}$ & 여 & 1 & 27 & $\mathrm{a}$ & 여 & 1 \\
\hline 12 & $\mathrm{~L}$ & 여 & 1 & 28 & $\mathrm{~b}$ & 여 & 1 \\
\hline 13 & $\mathrm{M}$ & 여 & 1 & 29 & $\mathrm{c}$ & 여 & 1 \\
\hline 14 & $\mathrm{~N}$ & 여 & 1 & 30 & $\mathrm{~d}$ & 여 & 1 \\
\hline 15 & $\mathrm{~N}$ & 여 & 1 & 31 & $\mathrm{e}$ & 여 & 1 \\
\hline 16 & 영인원 & & 1 & 32 & $\mathrm{f}$ & 여 & 1 \\
\hline
\end{tabular}

\section{2 자료수집방법}

본 연구의 자료 수집은 2020년 4월 27부터 5월6일까지 대면 비대면 온라인으로 실시되었으며 통일하면 생각나는 것, 통일의 필요성에 대한 예비유아 교사들의 생각, 통일되었을 때 화합을 위해 우선시 되어야 할 점에 대한 10 가지의 생각에 대해 개인적인 생각을 자유롭게 A4 용지에 기록하게 하였다. 소요 시간과 기록 방법은 자율적으로 이루어졌으며 기록된 연구물은 A4 용지로 총 59장이 수집되었다. 이들 연구 참여자들에게 이루어진 비대면 온라인면담은 비구조화된 면담이지만 연구 문제에 초점이 맞추어진 질문들이 선행되었다. 수집된 연구물에 대해 구체적인 사항은 대면과 비대면을 통해 소통하고자 하였다. 질문내용은 통일 교육 관련 내용을 벗어나지 않도록 한정하였고 이에 따른 주요 질문내용은 다음과 같다. '통일' 하면 생각나는 것은 무엇인가?, ‘통일' 필요성 여부는 어떠한가?, 통일된다면 남북한 사회의 화합을 위해 가장 우선시 되어야 할 점은 무엇인가? 이다.

\section{3 자료 분석}

본 연구에서 도출된 주제를 빈도와 백분율로 제시하고 주제에 따른 하위범주 내용을 제시하였다. 또한 수집된 자료를 통해 검토하여, 모든 자료를 아우르는 범주와 주제를 찾고자 하였다. 핵심적인 주제에 범주화된 자료들은 주제를 가장 잘 표현하는 단어를 찾아 범주에 적고, 범주화된 자료들의 목록을 유사성에 따라 줄여나갔다. 하위 범주화된 자료의 대표어는 연구 참여자들이 실제 사용한 언어를 사용하는 '인 비보(invivo)' 의 방식으로 작성하였다. 또한, 수집된 자료들을 반복적으로 읽으며 통합하고 분석하며, 심층적인 해석을 하고자 노력하였다. 자료의 분석 과정에서 연구자의 주관적인 해석과 
왜곡을 방지하고 연구의 객관성 유지를 위해 연구 참여자의 동의를 얻어 자료의 구성원 검토(member checking)를 받고 연구 결과의 해석을 검증받았다. 원자료와 다양한 자원의 자료를 지속적으로 확인하며 연구의 오류를 최소화하도록 주의하며 연구 결과의 타당성을 확보하기 위해 노력하였다.

\section{3. 결과 및 해석}

\section{1 사랑의 불시착을 넘어 통일이 떠올라요}

예비유아 교사들은 통일하면 생각나는 단어들에 대해 중복되어 나타난 단어들을 포함하여 총 527개의 단어가 도출되었으며 '통일' 하면 생각나는 것 중 61 개(11.6\%)를 쓴 $\mathrm{K}$ 예비유아 교사가 가장 많은 생각을 도출해 냈으며 $\mathrm{N}$ 예비유아 교사는 3 개 $(0,6 \%)$ 로 가장 적은 생각을 한 것으로 나타났다. '통일' 에 대한 생각에서 북한, 남한, 38 선, 이산가족, 다름, 독일, 경제, 문화 등이 가장 많이 도출되었고 최근에 방영된 '사랑의 불시착' 이라는 단어가 통일하면 생각나는 단어로 나타난 점은 미디어의 영향이 예비유아 교사들의 생각에 통일이라는 단어가 자연스럽게 스며들었음을 알 수 있었다. 연구 참여자의 ‘통일' 에 대해 생각나는 단어들에 대한 예비유아 교사들의 생각에 대한 빈도수는 [표 2]와 같다.

북한, 독재, $3 \cdot 8$ 선, $7 \cdot 4$ 남북공동성명, $6 \cdot 15$ 남북공동선언, 남북 조절 위원회, 한반도 비핵화 선언, 남북 정상회담, 개성공단, 이산가족, 금강산, 김구 선생님, 분단, 김정은, $6 \cdot 25$ 전쟁, 민주주의, 사회주의, 휴전, 언어, 경제, 문화, 다름, 차별, 한국사, 미국, 중국, 햇볕정책, 한반도, 하나, 한 민족, 평화, 경의선, 시베리아횡단철도, 평양, 판문점, 백두산, 군사력, 일자리, 기쁨, 그리움, 탈북, 북한 이탈주민 (사례 $4, \mathrm{D}$ 예비유아 교사)

독일, 경제, 문화, 이산가족, 통일 포스터, 통일 만화, 통일 표어, 감자, 음식, 축구, 서로 다른 중심부 도시의 풍경, 38선, 군인, 지뢰, 사랑의 불시착, 문화, 경제, 국가 예산, 앞으로의 정책, 한 나라의 지도자, 생각의 차이, 앞으로의 행정체계, 화합, 성장, 발전, 무궁화 (사례 15,0 예비유아 교사)

북한, 남한, 사랑의 불시착, 축구, 김정일, 공산주의, 사회주의, 민주주의, 대통령제, 북한 사투리, 아파트 안 닭장, 탁구, 올림픽, 이산가족, 시베리아 횡단 열차 (사례 16 , $\mathrm{P}$ 예비유아 교사)

[표 2] 연구 참여자의 통일에 대한 생각 빈도와 통일필요성 여부

[Table 2] Research Participants' Thoughts on Unification and whether Unification is Necessary

\begin{tabular}{|c|c|c|c|c|c|c|c|}
\hline 사례 & $\begin{array}{c}\text { 연구 } \\
\text { 참여자 }\end{array}$ & $\begin{array}{c}\text { 통일 } \\
\text { 빈도(개) }\end{array}$ & $\begin{array}{c}\text { 통일 } \\
\text { 필요유무 } \\
(\mathrm{Y} / \mathrm{N})\end{array}$ & 사례 & $\begin{array}{c}\text { 연구 } \\
\text { 참여자 }\end{array}$ & $\begin{array}{c}\text { 통일 } \\
\text { 빈도(개) }\end{array}$ & $\begin{array}{c}\text { 통일 } \\
\text { 필요유무 } \\
\text { (Y/N) }\end{array}$ \\
\hline 1 & $\mathrm{~A}$ & 17 & $\mathrm{Y}$ & 17 & $\mathrm{Q}$ & 10 & $\mathrm{Y}$ \\
\hline 2 & $\mathrm{~B}$ & 24 & $\mathrm{Y}$ & 18 & $\mathrm{R}$ & 6 & $\mathrm{Y}$ \\
\hline 3 & $\mathrm{C}$ & 12 & $\mathrm{~N}$ & 19 & $\mathrm{~S}$ & 5 & $\mathrm{~N}$ \\
\hline 4 & $\mathrm{D}$ & 43 & $\mathrm{~N}$ & 20 & $\mathrm{~T}$ & 6 & $\mathrm{Y}$ \\
\hline 5 & $\mathrm{E}$ & 17 & $\mathrm{Y}$ & 21 & $\mathrm{U}$ & 17 & $\mathrm{~N}$ \\
\hline 6 & $\mathrm{~F}$ & 16 & $\mathrm{Y}$ & 22 & $\mathrm{~V}$ & 6 & $\mathrm{Y}$ \\
\hline 7 & $\mathrm{G}$ & 18 & $\mathrm{Y}$ & 23 & $\mathrm{~W}$ & 5 & $\mathrm{~N}$ \\
\hline
\end{tabular}




\begin{tabular}{|c|c|c|c|c|c|c|c|}
\hline 8 & $\mathrm{H}$ & 13 & Y & 24 & $X$ & 10 & $\mathrm{~N}$ \\
\hline 9 & I & 35 & $Y$ & 25 & $\mathrm{Y}$ & 24 & $Y$ \\
\hline 10 & $\mathrm{~J}$ & 15 & $Y$ & 26 & Z & 49 & Y \\
\hline 11 & $\mathrm{~K}$ & 61 & $\mathrm{~N}$ & 27 & $\mathrm{a}$ & 6 & $Y$ \\
\hline 12 & $\mathrm{~L}$ & 10 & $Y$ & 28 & $\mathrm{~b}$ & 7 & $Y$ \\
\hline 13 & M & 19 & $Y$ & 29 & $\mathrm{c}$ & 8 & $Y$ \\
\hline 14 & $\mathrm{~N}$ & 3 & $\mathrm{~N}$ & 30 & $\mathrm{~d}$ & 5 & $Y$ \\
\hline 15 & 0 & 26 & $Y$ & 31 & $\mathrm{e}$ & 12 & $\mathrm{~N}$ \\
\hline 16 & P & 15 & $Y$ & 32 & $\mathrm{f}$ & 7 & Y \\
\hline \multicolumn{6}{|c|}{ 총 합계 } & 527 & $\begin{array}{l}\mathrm{Y}=23 \\
\mathrm{~N}=9\end{array}$ \\
\hline
\end{tabular}

\section{2 통일은 필요해요 YES 불안한 통일은 NO.}

통일은 필요한가에 대해 32 명 예비유아 교사 중 23 명(71.9\%)이 통일은 필요하다고 응답했으며 9 명 $(28.1 \%)$ 은 통일은 필요하지 않다고 응답하였다. 통일은 필요하다는 의견과는 다르게 통일이 필요하지 않다고 한 이유는 남한과 북한은 많은 것이 다르고, 국가 간의 이해와 존중이 부족하여 분열이 일어날 수 있고, 경제적 비용과 문화 차이가 심하기 때문에 통일을 반대하고 있었다. 연구참여자의 '통일' 의 필요성 여부는 위 [표 2]와 같다.

이미 너무 오랜 시간 분단이 되어서 다른 나라라고 생각합니다. 같은 점은 그저 한글을 사용한다뿐이지, 단어와 사상, 생활 습관, 하다못해 자음과 모음의 순서도 다릅니다. 이러한 상황까지 온 걸 보면 굳이 통일을 하기보단 그낭 독립된 국가로 나누어 자유롭게 왕래하는 것이 더 좋다고 생각합니다. (사례 $3, \mathrm{C}$ 예비유아 교사)

지금의 분단 아픔이나 경제적 피해를 생각한다면 통일이 필요한 것 같지만 내 생각은 조금 다르다. 통일한다면 분단의 아픔은 줄겠지만, 경제적이나 문화적 피해는 더 막심할 수 있다고 생각한다. 일단, 한국과 북한은 정치체제의 차이가 있다. 북한은 공산주의이 고 한국은 민주주의이다. 통일하게 된다면 정치체제가 하나로 통합되어야 하는데 그러는 과정에서 서로의 거센 반발이 생길 수 있고, 그 반발과 갈등으로 인해 통일하려다 서로 에 대한 악감정으로 더 안 좋은 상황이 발생할 수도 있다. 그렇게 된다면 우리나라뿐 아 니라 세계적으로 대한민국이라는 나라가 위협의 대상이 될 것이다. 또한, 정치체제를 통 합하였다고 해도 북한의 경제 수준은 우리나라보다 많이 떨어지며 빈부격차가 심하기 때 문에 북한의 사람들을 위해 우리나라의 경제적 지원이 필요하다. 지하자원만을 생각해 통일하려다 90년대로 돌아가는 상황이 발생할 수 있다고 생각한다. 아무리 북한에 많은 지하자원이 있다고 해도 바로 그 지하자원을 생산할 수 있는 것도 아니며, 북한의 경제 를 위해 한국의 발전이 멈추거나 퇴보하게 된다면 다시 성장하기에 오랜 시간이 걸릴 것 이다. 또한, 표준어를 통합하는데도 문제가 있을 것이다. 어느 지역의 말을 표준어로 사 용할지도 정해야 하는 일이고, 북한의 언어를 사투리로 사용한다고 한국에서 지정할 수 도 없는 처지다. 나는 통일을 하지 않고도 서로의 문화와 정치를 이해한다면 충분히 잘 지낼 수 있을 거로 생각한다. 유일한 분단국가라는 이름표는 붙겠지만 서로의 처지를 이 해하고 협의하면 충분히 이산가족의 아픔을 위한 정책이나 서로의 나라를 오가며 서로에 대한 불신과 두려움을 없앨 수 있다고 생각한다. 아무리 통일이 필요하고 중요하다고는 
말하지만, 서로의 평화와 행복이 가장 중요하기 때문에 서로의 문화와 정치에 대해 이해 하고 통일을 진행해도 늦지 않다고 생각하기 때문에 꼭 통일이 필요하다고 생각하지는 않는다. (사례 $11, \mathrm{~K}$ 예비유아 교사)

이미 언어나 문화의 격차가 크게 나기 때문에 굳이 통일이 필요하다고 생각하지 않는다. 통일보다는 북한이 개방하여 협력하는 것이 더 좋은 방법이라고 생각합니다. (사례 $14, \mathrm{~N}$ 예비유아 교사)

비록 남과 북이 한때 한 나라였지만, 전쟁을 통해 갈라진 지 무려 70 년이 넘었습니다. 그 사이 남한과 북한의 정치 체제가 달랐기 때문에 남과 북은 서로 다른 정치적 관점 및 성향을 가지고 살아가게 되었습니다. 만약, 통일된다면 공산주의와 자유민주주의를 놓고 싸우게 될 우려가 있는데 만에 하나 우리나라가 공산주의 국가가 되어버린다면 이제껏 우리나라가 쌓아놓은 위상과 그 모든 것들이 한순간에 사라질 수도 있다는 생각이 듭니다. 또한, 통일하게 된다면 현재 남한이 북한보다 훨씬 잘 살기 때문에, 경제 수준을 맞추기 위해서는 막대한 돈이 필요하고, 그 때문에 특히 남한 국민들에게 많은 세금을 요구하게 될 것입니다. 저는 이미 잘살고 있던 대한민국 국민들이 통일로 인해 피폐한 삶을 살 게 되는 것은 옳지 못한 일이라고 생각합니다. 또한, 통일세금은 꽤 오랫동안 지속할 것으로 생각합니다. 베를린 장벽을 무너뜨리고 통일을 했던 독일도 꽤 모범적인 통일 사례로 꼽히고는 있으나 여전히 많은 통일 세금을 내고 있다고 합니다. 비교적 안정적인 기반을 다지게 되었다고 평가받는 통일 국가조차 여전히 통일에 대한 세금을 내고 있는데, 우리나라의 통일이 실패할지 성공할지도 모르는 상황에서 통일을 시도하는 것은 너무 위험한 일입니다. 이러한 위험요소들에도 불구하고 단순히 한민족이었다는 이유로, 같은 언어를 쓴다는 이유만으로 통일을 시도하는 것은 옳지 못하다는 생각이 듭니다. 위와 같은 이유로 저는 대한민국과 북한 간의 통일을 반대합니다. ( 사례 31 , e 예비유아 교사)

\section{3 문화예술교류로 화합해요.}

예비유아 교사들은 통일이 된다면 남북한에서 가장 우선시되어야 할 화합을 위해 도출된 주제를 살펴보면 총 261 개의 내용이 도출되었다. 도출된 주제는 문화예술 체육, 음악, 문화교류(29개), 언어통합을 위한 한글의 재정비(27개), 경제적 격차 해소 및 화폐, 경제통합(27개), 교육과정 및 교육 필요성(19개), 하나의 정권, 정치체제의 통합(19개), 서로 다름 인정 및 이해와 존중(18개), 적대시하는 감정 버리기(14개), 국제사회에서 외교적 노력 필요(13개), 이산가족의 만남(12개), 서로 같은 민족 및 민족 동질성 회복(12개), 국가의 치안 및 준법의식의 화합(10개), 북한 사회 간접시설 확충하기(도로, 철도, 항만 등)(8개), 국방력 강화 및 군사 문제 화합(8개), 북한 주민에 대한 편견 무시 태도 바꾸기(7개), 역사자료 및 기록 재정비(6개), 남북한 격차 해소하기(5개), 핵 문제에 대한 합의(4개), 통일 한반도에 대한 생각의 일치(4개), 사회규범, 규칙, 가치체계 재정비(3개), 환경 기후적 요건 이해하기(3개), 의, 식, 주에 대한 화합 (3개), 일자리 창출(3개), 남북한 관광명소 방문 및 둘러보기(2개), 남북한 생활용품 공유하기(2개), 복지제도의 화합(2개), 자유와 평화에 대한 공유(1개) 등의 순서로 나타났으며 이러한 화합들이 우선시 될 때 남한과 북한이 하나로 통일이 될 수 있을 것이라 보았다.

남북한 사회의 화합을 위해 가장 우선시 되어야 할 점은 언어통일, 이산가족 문제 
해결, 교통 정비, 교육 과정 통일, 사상, 화폐, 금강산 되찾기, 국기, 국가(노래), 자원 분배라고 생각한다. 만약에 통일이 된다면 사람들은 사상적으로 혼란이 있을 것이기 때문에 어떤 사상을 중점으로 둔 통일인지를 정확히 명시해 주어야 한다. 또한, 현재 북한과 남한의 경제적인 요건 및 교통의 차이가 심할 것이기 때문에 수평적으로 맞추는 정책들을 우선시해야 할 것이다. 동시에 통일 후 가장 급한 것은 오랜 시간 만나지 못했던 가족들에게 하루빨리 만날 수 있도록 도와주는 것으로 생각하기 때문에 이산가족 상봉 지원을 적극적으로 해야 한다고 생각한다. 더불어, 사람들과 소통하며 문화를 나누고 잘 지내려면 언어적 차이를 좁히고, 화폐의 가치를 동등하게 조정해야 하며, 초등, 중등교육 과정의 통일로 평등한 교육을 제공할 수 있도록 해야 한다. 만약에 교육과정의 통합이 없다면 불평등한 교육이 진행될 것이다. 당연히 유아교육의 보편화를 시켜 북한의 아이들도 유아기에만 할 수 있는 적기교육을 할 수 있도록 지원해서 교육을 받을 수 있도록 해주어야 할 것이다. (사례 $16, \mathrm{P}$ 예비유아 교사)

통일된다면 하나의 정권이 나라를 운영해 나가야 하기에 정치 차원에서의 통합이 이루어져야 한다. 통일된다면 화폐 및 산업 구조가 단일화되어야 하기에 경제 차원에서의 통합이 이루어져야 한다. 통일이 된다면 북한 이탈 주민에 대한 우리의 인식을 바꾸어, 북한 출신이라는 편견을 가지고 북한 이탈 주민을 바라본다거나 무시하는 태도를 지니지 않도록 해야 한다. 통일된다면 새로운 사회를 지탱해 줄 수 있는 새로운 규범이나 가치 체계를 재정비하여 재사회화를 통한 사회통합을 이룰 수 있도록 해야 한다. 통일된다면 통일 이후의 혼란을 막기 위해 남북한의 다른 언어에 대한 연구와 조사를 선행하여 한글 통일안이 시급하게 수립될 수 있도록 해야 한다. 통일된다면 남북한의 사회문화적 동질성을 확보하기 위해 문화예술-체육 등 다양한 분야에서 문화교류가 이루어져야 한다. 통일된다면 국가의 치안을 위해 북한 주민들에게 준법 의식에 관련하여 자발적 참여를 유도하고 강제적 행동을 통한 교정 캠페인을 시행해야 한다. 통일된다면 남북한의 역사적 자료 및 기록들을 재정비해야 한다. 북한 측에서 정치적 선전에 사용하기 위해 왜곡한 자료들이 많기 때문이다. 통일된다면 남북한은 서로의 다름을 인정하고 포용하는 자세를 기를 수 있도록 해야 한다. 통일된다면 남북한의 경제적 격차로 인해 지역 갈등이 발생할 수도 있기 때문에 통일 전후 과정에서 북한 지역 경제의 활성화와 안정적 관리를 도모해야 한다. (사례 $1, \mathrm{~A}$ 예비유아 교사)

1. 단어 통합하기, 단어가 통합된다면 우리도 여러 북한의 단어들을 배우게 될 것이다. 2. 군인제도 폐지하기(직업군인 제외), 군인제도가 폐지된다면 많은 남자가 선호할 것이다. 3 . 핵 없애기 (핵 문제 해결), 핵 문제가 해결된다면 많은 사람이 안심하게 될 것이다. 4. 지도자 통합하기, 지도자가 통합된다면 새로운 정책들이 생겨날 것이다. 5. 교육 통합하기, 교육이 통합된다면 교사들은 새로운 교육에 관해 공부해야 할 것이고 아이들과 새로운 개념들을 배우게 될 것이다. 6. 문화 통합하기, 문화가 통합된다면 남한과 북한이 만나 새로운 문화가 또 생겨날 수도 있을 것이다. 7. 남북한이 함께하는 캠페인 열기, 캠페인이 개최된다면 서로가 더 친해질 수 있는 계기가 될 것이다. 8. 법 개정하기, 법을 개정한다면 기존의 법과 다른 법이 생겨나 많은 사람이 그것에 적응하는 데에 혼란스러울 것이다. 9. 각 나라의 문화를 체험해볼 수 있는 체험활동 열기, 체험활동을 할 수 있게 된다면 남한과 북한 모두 많은 경험을 통해 새로운 경험을 할 수 있게 될 것이다. 10 . 재산 어느 정도 균등하게 하기, 북한과 남한의 경제 관념과 소득의 차이가 크게 나기 때문에 어느 정도 균등하게 맞춘다고 
한다면 이에 반발하는 사람이 분명히 있을 것이다. ( 사례 $18, \mathrm{R}$ 예비유아 교사)

\section{4. 논의 및 결론}

본 연구에서 '통일' 하면 생각나는 것, ‘통일' 의 필요성 유무, 통일된다면 남북한 사회의 화합을 위해 가장 우선시 되어야 할 점 10 가지 가정적 글쓰기를 통해 예비유아 교사들의 생각에 대해 알아보고자 한 양적, 질적 연구를 수행한 혼합연구이다. 예비유아 교사들의 생각과 글쓰기 활동은 연구 참여자들에게도 의미 있는 경험임을 알 수 있었다. 시대적 흐름이 화합으로 흘러가고 있고 남한과 북한이 서로의 주장을 펴기보다는 이해와 소통, 공감하려는 모습들이 보임으로써 예비유아 교사들은 통일이 먼 미래가 아닌 우리가 손을 벌리면 닿을듯한 거리에 왔음을 인식하고 있었다. 교육패러다임의 변화보다는 문화예술, 체육, 음악 문화교류에 의미를 두고 있었다. 또한, 통일 후 교육의 변화와 예비 유아 교사로서 준비할 것에 대해 생각하려는 모습도 보여줬다. 통일을 통해 예비 유아 교사들이 만나게 될 통일 교육은 커다란 틀은 변화하지 않을 것이고 자신들이 현재하고 있는 교육과정에서 그들이 할 수 있는 교육영역의 패러다임 속에서 크게 벗어나지 않는 선에서 통일 후 교육의 변화와 예비유아 교사로서 준비할 것을 찾으려고 노력하는 모습을 보여줬다. 그러므로 예비유아 교사들의 통일 교육에 대한 생각은 다음과 같은 측면에서 의미가 부여되었으며, 본 연구결과를 중심으로 다음과 같이 논의하고자 한다.

첫째, ‘통일' 하면 생각나는 527 개의 단어가 도출되었으며 현재의 남북한 상황이 반영된 단어들이 도출된 점과 드라마 속 북한 이야기 등이 예비유아 교사들에게 사고하여 글로 표현할 좋은 기회였던 것 같다. 초.중·고 학교통일 교육인 북한 이해, 통일문제이해, 통일 안보 교육, 대북관계 등을 통해 통일에 대한 인식이 되어있음을 사료된다. 이러한 점은 학교통일 교육 실태조사 결과보고서와도 일치하며(통일부. 통일교육원, 2018)[9], 통일에 대한 예비유아 교사의 인식은 북한이해, 남북한 국가개념, 통일의 당위성, 통일 이후 사회변화에 대한 인식으로 나누어 살펴본 김선혜(2020) 연구에서도 찾아볼 수 있었다[7].

둘째. '통일' 의 필요성 여부에 대해서는 23 명 $71.9 \%)$ 의 모든 예비유아 교사들이 긍정적인 응답을 하였지만 9 명 $(28.1 \%)$ 은 통일은 필요하지 않다는 응답을 한 것으로 나타났다. 이러한 결과는 최정란(2017)의 연구 결과 통일 이후 정치적 갈등 심화와 경제성장에서의 어려움이 발생할 것으로 예상되거나 사회복지 향상 적 측면에서도 부정적인 결과가 예측될 것이라는 점 등은 유아 교사들과의 생각과 일치됨을 알 수 있다[5]. 또한 권종애(2018)의 연구에서는 모든 유아 교사들이 통일은 이루어져야 한다고 보았고, 통일 후 유아 교사로서 교육패러다임의 변화, 통일을 준비하려는 자세와 태도, 자신들의 역량 개발을 위해 다양한 노력을 할 것이라는 연구 결과와는 차이가 있는 것으로 여겨진다[2].

김선혜(2020)의 연구에서 통일 교육의 필요성은 예비유아 교사의 통일 교육 경험에 따라 통일 교육에 대한 인식의 차이가 크다는 것을 알 수 있었다. 유아 교사는 교육의 질을 결정하는 중요한 요인이므로 교사로서 전문성 신장을 위해 교원양성기관에서 부터 예비유아 교사를 위한 통일 교육이 필요함을 시사한다[7]

셋째, 통일 이후 남북한 사회의 화합을 위해 가장 우선시 되어야 할 점 10가지 글쓰기에서 가장 많은 예비유아 교사들의 생각은 문화예술 체육, 음악, 문화교류이었다. 
다음으로 언어통합을 위한 한글의 재정비, 경제적 격차 해소 및 화폐, 경제통합, 교육과정 및 교육 필요성에 대한 생각을 이야기하고 있었다. 이러한 결과는 권종애(2018) 연구에서 유아 교사들은 교육제도의 화합, 교육과정, 및 학제 개편에 대한 현장의 직접적인 이야기에 긍정적이었다는 점에서 차이가 있음을 알 수 있다. 이러한 교사들의 사고는 현재 자신이 속한 유아 교사, 예비유아 교사의 상황에서 가장 우선시 생각할 수 있는 사고라 여겨진다고 해석할 수 있겠다[2]. 이러한 점은 통일 교육이 꼭 필요하고, 다양한 연수와 교사 교육을 통해 남한과 북한이 함께할 교육의 화합을 준비하고자 하는 교사들의 의지로 여겨진다(김보영, 2015; 이경하, 2017; 최정란, 2017)[3][5][10].

이와 같은 결론을 기초로 하여 다음과 같이 본 연구의 제한점과 후속 연구에 대한 제언을 하고자 한다.

첫째, 예비유아 교사에게 대학별 통일 교육 및 통일 교육 연수가 필요하다.

둘째, 예비유아 교사들을 위한 통일 교육 프로그램개발이 필요하다.

셋째, 예비유아 교사들을 위한 교육 변화에 적응 할 수 있고, 수업 준비를 위한 다양한 유아 통일 교육의 내용을 통한 양적, 질적 연구가 필요하다.

넷째, 예비유아 교사들이 2019 개정 누리과정에서 통일 교육의 현장 적용방안에 대한 교수학습 방법이 필요하다.

\section{References}

[1] C. S. Lee, A Study on the Democratic Citizenship Educational Approach of Unification Education, Seoul National University of Education Graduate School, Master's thesis, pp.1-55, (2020)

[2] J. A. Kwon, Early childhood teachers' perspectives on unification education, korean Jouranl of Early Childhood Education, (2018), Vol.20, No.4, pp.149-170.

[3] B. Y. Kim, Kindergarten teachers' perception and current status of early childhood unification education: Focusing on Incheon Metropolitan City, Incheon University Graduate School of Education, Master's thesis, pp.1-79, (2015)

[4] M. H. Park, A study on the perception type of daycare center teachers on unification education using Q methodology, Chongshin University Graduate School of Education, Master's thesis, pp.1-69, (2018)

[5] J. R. Choi, A study on the perception of early childhood teachers on unification education and the current state of the curriculum, Hansung University Graduate School of Education, Master's thesis, pp.1-98, (2017)

[6] Y. M. Kwak, Unification education competency according to human variables of early childhood teachers, Chongshin University General Graduate School, Master's thesis, pp.1-64, (2011)

[7] S. H. Kim, Awareness of unification and unification education of pre-school teachers, Chongshin University Graduate School of Education, Master's thesis, pp.1-94, (2020)

[8] S. W. Kim, S. Y. Kim, The effect of "Unification" project on young children's unification perception, and conflict perception and resolution, The Journal of Korea Open Association for Early Childhood Education, (2019), Vol.24, No.4, pp.293-315, DOI: 10.20437/KOAECE24-4-13

[9] Unification Education Master Plan (2019-2021) and Implementation Plan for 2019, National Institute for Unification Education, pp.1-238, (2019)

[10] K. H. Lee, A Study on the Recognition of the Korean Reunification for the Early Childhood Teachers, Hansung University Graduate School of Education, Master's thesis, pp.1-90, (2017) 